\title{
IMPLEMENTASI ETIKA BISNIS PERSPEKTIF ISLAM
}

\author{
Khoiruddin \\ Institut Agama Islam Negeri (IAIN) Raden Intan Lampung \\ alfan_abiya@yahoo.co.id \\ Judul : Islamic Business and Economic Ethics: Mengacu pada al-Qur'an \\ dan Mengikuti Jejak Rasulullah SAW dalam Bisnis, Keuangan, \\ dan Ekonomi \\ Penulis $\quad$ : Veithzal Rivai, Amiur Nuruddin, dan Faisar Ananda Arfa \\ Penerbit : : Bumi Aksara \\ Tahun : 2012 \\ Tebal : 555 hal.
}

\section{Pendahuluan}

Ada tiga aspek bangunan utama dalam Islam, yaitu aspek aqidah (iman), aspek syari'ah (islam), dan aspek akhlak (ihsan) (Karim, 2004: 3). Aspek aqidah adalah aspek yang berhubungan dengan masalah-masalah dan dasar-dasar keagamaan (ushuluddin). Aqidah sering disebut sebagai ruh bagi kehidupan setiap manusia. Aspek syari'ah adalah peraturan dan hukum yang berisi perintah dan larangan yang dibebankan oleh Allah kepada manusia. Walaupun hakekatnya syari'at tersebut bersumber dari Allah, namun tidak seperti aqidah yang sifatnya konstan dan kekal, syari'ah lebih leluasa dan bisa mengalami interpretasi sesuai dengan perkembangan peradaban manusia (QS. 5: 48).

Sedangkan aspek akhlak, yang sering disebut sebagai etika dan ihsan, yang berarti baik. Masalah ihsan sangat terkait dengan baik-buruk, indah-jelek. Defenisi ihsan dinyatakan sendiri oleh nabi dalam haditsnya, "ihsan adalah engkau beribadat kepada Tuhanmu seolah-olah engkau melihatnya sendiri, kalupun engkau tidak melihat-Nya, maka Ia melihatmu”. Ihsan (akhlak) yang dinyatakan oleh nabi dalam haditsnya tersebut, menunjukkan bahwa akhlak juga memberikan panduan bagaimana orang berprilaku terhadap Allah, dan juga terhadap sesama makhluk lainnya (Zainal, 1979: 24). 
Bila dilihat dari tiga aspek yang mendasari ajaran Islam tersebut, jelaslah bahwa Islam tidak hanya memperhatikan ibadah (hablum minallah), tapi juga memperhatikan hal-hal yang sifanya mua'malah, yaitu mengatur hubungan manusia dengan sesamanya (hablum minannas), yang meliputi berbagai aspek ajaran mulai dari persoalan hak atau hukum (the right) sampai kepada urusan perekonomian yaitu lembaga keuangan (Muhamad, 2000: 3). Dalam bidang mua'malah khususnya masalah perekonomian, Islam juga sangat memperhatikan unsur etika dalam pelaksanaannya. Islam melarang unsur eksploitasi berupa riba dan transaksi-transaksi yang belum jelas bentuknya, yaitu gharar.

Islam menekankan adanya moralitas seperti persaingan yang sehat, kejujuran, keterbukaan, dan keadilan. Implementasi nilai-nilai moralitas tersebut dalam bisnis merupakan tanggung jawab bagi setiap pelaku bisnis. Bagi seorang muslim, nilai-nilai ini merupakan refleksi dari keimanannya kepada Allah, bahkan Rasulullah memerankan dirinya sebagai muhtasib. Beliau menegur langsung transaksi perdagangan yang tidak mengindahkan nilai-nilai moralitas (Rahman, 1997: 5).

Buku Islamic Business and Economic Ethics ini membahas topik yang sangat diperlukan oleh praktisi dan akademisi, bahkan selalu menarik untuk didiskusikan, dengan harapan dapat dibandingkan dengan karya-karya yang lain. Buku ini padat dengan teori dan dilengkapi dengan konsep yang aktual, prosedur, dan praktik kerja nyata yang pernah diperaktikkan oleh Rasullullah SAW beberapa abad yang silam.

\section{Etika Ekonomi dan Bisnis Islam}

Istilah etika (ethics) berasal dari kata Yunani, yaitu ethos (bentuk tunggal) yang berarti adat istiadat (kebiasaan), perasaaan batin, kecenderungan hati untuk melalukan perbuatan, watak, sikap, cara berpikir. Bentuk jamaknya adalah ta etha, yang berarti adat istiadat (Abdullah, 2006: 4).

Etika adalah refleksi dari apa yang disebut dengan "self control", karena segala sesutunya dibuat dan diterapkan dari dan untuk kepentingan kelompok itu sendiri. Dengan kata lain bahwa etika lebih bersifat teoritis. Etika hanya berbicara 
mengenai nilai perbuatan baik dan buruknya manusia dengan tolak ukur akal pikiran.

Istilah yang sering dipakai senonim dengan etika adalah moral. Moral berasal dari kata Latin, yaitu mos (bentuk tunggal), dan mores, atau moralis (bentu jamak) yang berarti adat istiadat, kebiasaan, kelakuan, watak, tabiat, akhlak, cara hidup (Agoes, 2009: 26). Secara umum keduanya baik moral dan etika mengandung arti "kebiasaan atau cara hidup". Walaupun kedua istilah tersebut sering dipakai sebagai sinonim. Namun dalam perkembangannya "morality" lebih dipakai untuk menunjukkan "tingkah laku", sedangkan "ethics" menunjukkan kepada "penyelidikan tentang tingkah laku”. Disebut sebagai "moral act" dan "ethical code" (Titus, 1984: 141).

Pada dasarnya secara konseptual paradigmatik, kedua istilah baik etika maupun moral, mempunyai sentralitas pengertian dan obyek yang sama, yaitu sama-sama membicarakan totalitas tingkah laku manusia dari sudut pandang nilainilai yang baik dan buruk. Akan tetapi pada dataran realitas penggunaannya kedua istilah tersebut memiliki sedikit perbedaan dalam nuansa aplikatifnya. Moral atau moralitas dipakai sebagai tolok ukur menilai suatu perbuatan yang sedang dilakukan oleh seseorang. Sementara etika digunakan sebagai kerangka pemikiran untuk mengkaji sistem-sistem nilai atau kode (Said, 1980: 23).

Dijelaskan dalam buku ini (Islamic Business and Economic Ethics) istilah etika memilik beragam makna. Salah satu-nya adalah "prinsip tingkah lagu yang mengatur individu dan kelompok". Dijelaskan bahwa etika adalah "kajian moralitas". Walaupun etika kajian moralitas, tetapi etika tidak sama dengan moralitas. Etika merupakan penelaahan atau hasil dari penelaahan itu sendiri, sedangkan moralitas merupakan subjek. Etika merupakan ilmu yang mendalami standar moral perorangan dan standar moral masyarakat (Rivai, 2012: 3).

Etika dalam islam disebut dengan akhlak. Dalam Kamus Besar Bahasa Indonesia, kata akhlak diartikan sebagai budi pekerti atau kelakuan. Kata akhlak walaupun terambil dari bahasa Arab (yang biasa berartikan tabiat, perangai kebiasaan, bahkan agama), namun kata seperti itu tidak ditemukan dalam al-Qur'an. Yang ditemukan hanyalah bentuk tunggal kata tersebut, yaitu 
khuluq yang tercantum dalam QS. al-Qalam ayat 4 (Shihab, 2004: 78). Ayat tersebut dinilai sebagai konsideran pengangkatan Nabi Muhammad Saw. sebagai Rasul:

"Sesungguhnya engkau (Muhammad) berada di atas budi pekerti yang agung." (QS. 68: 4).

Sebagaimana dikungkapkan oleh Ahmad Amin, bahwa etika atau akhlak dalam khazanah Islam dipahami sebagai ilmu yang menjelaskan baik dan buruk, menerangkan apa yang seharusnya dilakukan kepada orang lain, menyatukan tujuan apa yang harus dituju oleh manusia di dalam perbuatan mereka dan menunjukan jalan untuk melakukan apa yang harus diperbuat (Amin, 1995: 3).

Dengan demikian persoalan-persoalan etika adalah persoalan kehidupan manusia. Tidak bertingkah laku semata-mata menurut naluri atau dorongan hati. Hal ini menunjukkan bahwa ahklak merupakan gambaran bentuk lahir manusia (Nasir, 1991: 14).

Ibn Maskawih menyatakan bahwa akhlak adalah "keadaan jiwa seseorang yang mendorongnya untuk melalukan perbuatan-perbuatan tanpa melalui pertimbangan pikiran (terlebih dahulu)". Ahmad Amin memberikan defenisi akhlak adalah suatu ilmu yang menjelaskan arti baik dan buruk, menerangkan apa yang harusnya dilakukan oleh sebagian manusia kepada manusia lainnya, menyatakan apa yang harus dituju oleh manusia dalam hal perbuatan mereka dan menunjukkan jalan apa yang harus diperbuat.

Sedangkan menurut A. Mustofa akhlak dalam Islam (akhlak Islam) adalah merupakan sistem moral atau akhlak yang berdasarkan Islam, yakni bertitik tolak dari akidah yang diwahyukan Allah pada Nabi atau Rasul-Nya yang kemudian disampaikan pada umatnya (Mustofa, 1997: 149).

Akidah tersebut diwujudkan menjadi tabiat atau sifat seseorang, yakni telah biasanya dalam jiwa seseorang yang benar-benar telah melekat sifat-sifat yang melahirkan perbuatan-perbuatan dengan mudah dan spontan tanpa dipikirkan. Perbuatan tersebut terkadang berbentuk baik dan terkadang juga berbentuk buruk. 
Dengan demikian pada tahap pertama merupakan hasil pemikiran atau pertimbangan tetapi lama-lama menjadi melekat dan tanpa pertimbangan dan pemikiran. Dapat dikatakan akhlak merupakan manifestasi iman, Islam dan ihsan yang merupakan repleksi sifat dan jiwa secara spontan yang terpola pada diri sendiri sendiri sehingga dapat melahirkan perilaku secara konsisten dan tidak tergantung pada pertimbangan interes tertentu (Sidiktono, 1998: 89).

Dalam buku Islamic Business and Economic Ethics, persoalan-persoalan etika bisnis islam dibahas secara gamblang. Mulai dari pengertian etika, etika produksi dan konsumsi islam, juga penerapan etika pada organisasi bisnis. Untuk pengertian etika tidak jauh berbeda dari pengertian tersebut di atas. Sedangkan etika produksi Pandangan islam tentang produksi bertentangan dengan produksi dalam konvensional yang mengutamakan self interest. Dalam islam kegiatan produksi pada hakekatnya adalah ibadah. Sehingga tujuan dan prinsipnya harus dalam kerangka ibadah. Perusahaan tidak hanya mementingkan keuntungan pribadi dan perusahaan namun juga memberikan kemaslahatan bagi masyarakat dengan tidak mengabaikan lingkungan sosialnya (Rivai, 2012: 276).

Konsumsi berlebih-lebihan, merupakan ciri khas masyarakat yang tidak mengenal Tuhan, dikutuk dalam Islam dan disebut dengan istilah israf atau tabzir. Tabzir berarti mempergunakan harta dengan cara yang salah, yakni untuk menuju tujuan-tujuan yang terlarang seperti penyuapan, hal-hal yang melanggar hukum atau dengan cara yang tanpa aturan. Setiap kategori ini mencakup beberapa jenis penggunaan harta yang hampir-hampir sudah menggejala pada masyarakat yang berorientasi konsumer. Pemborosan berarti penggunaan harta secara berlebihlebihan untuk hal-hal yang melanggar hukum dalam hal seperti makanan, pakaian, tempat tinggal atau bahkan sedekah. Ajaran-ajaran Islam menganjurkan pola konsumsi dan penggunaan harta secara wajar dan berimbang, yakni pola yang terletak diantara kekikiran dan pemborosan. Konsumsi di atas dan melampaui tingkat moderat (wajar) dianggap israf dan tidak disenangi Islam, dengan kata lain menyalahi etika konsumsi islami (Rivai, 2012: 174). 
Untuk penerapan etika bisnis pada organisasi perusahaan, dijelaskan dalam buku ini (Islamic Business and Economic Ethics) bahwa ada dua pandangan, pertama jika perusahaan bertindak sesuai aturan (standar moral) maka dapat dikatakan perusahaan itu bertindak sesuai moral. Kedua, tidak masuk akal jika perusahaan bertanggung jawab jika ia gagal mengikuti standar moral. Organisasi (perusahaan) tidak punya kewajiban moral. Dimana perusahaan adalah seperti mesin yang hanya mengikuti peraturan formal yang tidak ada kaitannya dengan moralitas (Rivai, 2012: 5).

\section{Pedoman Bisnis dalam Islam}

Bisnis Islami ialah serangkaian aktivitas bisnis dalam berbagai bentuknya yang tidak dibatasi jumlah kepemilikan (barang/jasa) termasuk profitnya, namun dibatasi dalam cara memperolehnya dan pendayagunaan hartanya karena aturanaturan islam (halal dan haram) (QS. 2: 188, 4: 29).

Dalam pandangan Islam, sebagaimana disebutkan dalam al-Qur'an bahwasanya dianjurkan kepada manusia untuk melakukan segala aktivitas dan tidak memberi peluang bagi seorang muslim untuk menganggur. Islam melarang seseorang untuk putus asa (dalam bekerja), sebagaimana disebutkan dalam alQur'an "faiza faraghta fanshab", yang artinya, "Maka apabila engkau telah menyelesaikan (suatu urusan), berdirilah (segera untuk urusan yang lain) (QS. 94: 7).

Kata faraghta yang terambil dari kata faragha mengandung arti "kosong" setelah sebelumnya penuh. Kata ini digunakan untuk melukiskan kekosongan yang didahului oleh kepenuhan. Seseorang yang telah memenuhi waktunya dengan pekerjaan, kemudian ia menyelesaikan pekerjaan tersebut, maka jarak waktu antara selesainya pekerjaan pertama dan dimulainya pekerjaan berikutnya dinamakan faragh.

Hal tersebut menunjukkan bahwa al-Qur'an menekankan kepada manusia, kaum muslimin khususnya, agar selalu kerja dan kerja keras. Dimana kerja dan kerja keras harus dijadikan sebagai prinsip dasar hidup bagi kaum muslimin. Sebagaimana firman Allah SWT: 
"dan bahwasanya seorang manusia tiada memperoleh selain apa yang telah diusahakannya”. (QS. 53: 39).

Dalam melakukan bisnis atau usaha tentulah seseorang perlu bekerja. Bekerja adalah sebuah aktivitas yang menggunakan daya yang dimiliki oleh manusia yang merupakan pemberian Allah. Sikap islam terhadap kerja dapat dilihat dari banyaknya ayat-ayat al-Qur'an yang memerintahkan manusia untuk bekerja.

Pedoman secara umum tentang masalah kerja, yaitu Islam tidak membolehkan pengikut-pengikutnya untuk bekerja mencari uang sesuka hatinya dan dengan jalan apapun yang dimaksud, seperti penipuan, kecurangan, sumpah palsu, dan perbuatan batil lainnya. Tetapi Islam memberikan kepada mereka suatu garis pemisah antara yang boleh dan yang tidak boleh dalam mencari perbekalan hidup, dengan menitikberatkan juga kepada masalah kemaslahatan umum, seperti suka sama suka sehingga tidak ada pihak yang merasa dirugikan dan dizalimi dalam transaksi tersebut. Garis pemisah ini berdiri di atas landasan yang bersifat kulli (menyeluruh) yang mengatakan bahwa semua jalan untuk berusaha mencari uang yang tidak menghasilkan manfaat kepada seseorang kecuali dengan menjatuhkan orang lain, adalah tidak dibenarkan. Semua jalan yang saling mendatangkan manfaat antara individu-individu dengan saling rela-merelakan dan adil, adalah dibenarkan. Prinsip ini telah ditegaskan oleh Allah dalam firman-Nya:

"Hai orang-orang yang beriman! Jangan kamu memakan harta-harta saudaramu dengan cara yang batil, kecuali harta itu diperoleh dengan jalan dagang yang ada saling kerelaan dari antara kamu. Dan jangan kamu membunuh diri-diri kamu, karena sesungguhnya Allah Maha Pengasih kepadamu. Dan barangsiapa berbuat demikian dengan sikap permusuhan dan penganiayaan, maka kelak akan Kami masukkan dia ke dalam api neraka." (QS. 4: 29-30).

Ayat ini memberikan syarat boleh dilangsungkannya perdagangan dengan dua hal. Pertama, perdagangan itu harus dilakukan atas dasar saling rela antara kedua belah pihak. Tidak boleh bermanfaat untuk satu pihak dengan merugikan pihak lain. Kedua, tidak boleh saling merugikan baik untuk diri sendiri maupun orang lain. 
Dengan demikian ayat ini memberikan pengertian, bahwa setiap orang tidak boleh merugikan orang lain demi kepentingan diri sendiri (vested interest). Sebab hal demikian, seolah-olah dia menghisap darahnya dan membuka jalan kehancuran untuk dirinya sendiri. Misalnya mencuri, menyuap, berjudi, menipu, mengaburkan, mengelabui, riba, pekerjaan lain yang diperoleh dengan jalan yang tidak dibenarkan.Tetapi apabila sebagian itu diperoleh atas dasar saling suka sama suka, maka syarat yang terpenting jangan kamu membunuh diri kamu itu tidak ada (Qardhawi,1993: 38).

Selain perintah untuk "bekerja" (melakukan aktivitas) dalam islam yang menunjukkan istilah "bisnis" (secara umum), terdapat beberapa istilah lain yang lebih khusus dalam al-Qur'an yang dapat dipadankan dengan apa yang dimaksud dengan bisnis. Diantaranya adalah istilah al-tijarah, al-bai', tadayantum, dan isytara (Bentuk tijarah terdapat dalam QS. 2: 282, 4: 29, 9: 24, 24: 37, 35: 29, 61: 10, 62: 11. Tijaratuhum 2: 16).

Kata at-tijarah berasal dari kata dasar tajara, tajran, tijaratan, yang bermakna berdagang atau berniaga. Untuk kata at-tijaratun, mutjar mengandung arti pendagangan, perniagaan (Baqi, 1981: 152).

Hal yang sama dengan aktivitas bisnis yaitu kata shina'atun, shan'atun berasal dari kata dasar shana'a, yang artinya "pekerjaan", yang maknanya menjadi "perindustrian" (shina'atun) dan industrialisasi (at-tashni'un). Dapat dijumpai juga kata bermakna bisnis yaitu ihtarafa (dari kata hirfatun, berasal dari kata dasar harafa) yang mengandung arti "mencari nafkah", ahrafa bermakna "bekerja keras untuk mencari nafkah keluarga untuk kaya" (Munawir, 1984: 139, 852, dan 274).

Untuk kata al-bai' bermakna “jual beli”. Baya'tum, bibai'ikum, dan tabaya'tum, digunakan dalam pengertian jual beli yang dilakukan oleh kedua belah pihak dengan ketelitian, terbuka dan dengan tulisan (QS. 9: 111, 2: 282). Sedangkan isytara bermakna "membeli". Secara umum kata isytara dalam alQur'an mengandung makna transaksi dengan tujuan keuntungan (Muhammad, 2004: 51-53). Untuk kata tadayantum yang disebutkan 1 kali dalam al-Qur'an 
digunakan dalam pengertian muamalah, yaitu jual beli, utang piutang, sewa menyewa (QS. 2: 282).

Dari pengertian-pengertian padanan istilah-istilah bisnis dalam al-Qur'an yang disebutkan di atas, baik al-tijarah, al-bai', tadayantum, maupun isytara, kesemuanya diperlihatkan dalam konteks sebagai bisnis (perspektif umum), yaitu sebagai media mencari penghidupan. Dimana media tersebut pada hakekatnya tidak semata-mata bertujuan mencari keuntungan material semata, tetapi bersifat material dan immaterial, bahkan lebih mengutamakan hal yang bersifat immaterial dan kualitas.

Dengan kata lain, bahwa bisnis dalam islam, sebagaimana dalam al-Qur'an mempunyai sifat yang khusus, dengan tidak bertujuan jangka pendek saja, hanya semata-mata keuntungan dalam pandangan manusia, tetapi juga bertujuan jangka pendek dan jangka panjang, yaitu keuntungan dan kebahagiaan abadi.

Sebagaimana ditulis dalam buku ini (Islamic Business and Economic Ethics), keberkahan usaha merupakan kemantapan memperoleh keuntungan yang wajar dan dirdhai oleh Allah swt. Untuk memperoleh keberkahan dalam jual beli, islam mengajarkan prinsip-prinsip moral, yaitu jujur dalam menakar dan menimbang, menjual barang yang halal, menjual barang yang baik mutunya, tidak menyembunyikan cacat barang, tidak melakukan sumpah palsu, longgar dan murah hati, tidak menyaingi penjual lain, tidak melakukan riba, dan mengeluarkan zakat bila telah sampai nisab dan haulnya (Rivai, 2012: 28).

Sebagaimana dikatakan oleh Muhammad Ismail Yusanto dan Muhammad Karebet Widjajakusuma, bahwa bisnis dalam Islam bertujuan untuk mencapai empat hal utama (Yusanto, 2002: 18), yaitu:

1. Target hasil: profit-materi dan benefit-nonmateri.

Target hasil: profit-materi dan benefit-nonmateri, artinya bahwa bisnis tidak hanya untuk mencari profit (qimah madiyah atau nilai materi) setinggitingginya, tetapi juga harus dapat memperoleh dan memberikan benefit (keuntungan atau manfaat) nonmateri kepada internal organisasi perusahaan dan eksternal (lingkungan), seperti terciptanya suasana persaudaraan, kepedulian sosial dan sebagainya. 
Benefit, yang dimaksudkan tidaklah semata memberikan manfaat kebendaan, tetapi juga dapat bersifat nonmateri. Islam memandang bahwa tujuan suatu amal perbuatan tidak hanya berorientasi pada qimah madiyah. Masih ada tiga orientasi lainnya, yakni qimah insaniyah, qimah khuluqiyah, dan qimah ruhiyah. Dengan qimah insaniyah, berarti pengelola berusaha memberikan manfaat yang bersifat kemanusiaan melalui kesempatan kerja, bantuan sosial (sedekah), dan bantuan lainnya. Qimah khuluqiyah, mengandung pengertian bahwa nilai-nilai akhlak mulia menjadi suatu kemestian yang harus muncul dalam setiap aktivitas bisnis sehingga tercipta hubungan persaudaraan yang Islami, bukan sekedar hubungan fungsional atau profesional. Sementara itu qimah ruhiyah berarti aktivitas dijadikan sebagai media untuk mendekatkan diri kepada Allah SWT.

\section{Pertumbuhan}

Jika profit materi dan profit non materi telah diraih, perusahaan harus berupaya menjaga pertumbuhan agar selalu meningkat. Upaya peningkatan ini juga harus selalu dalam koridor syariah, bukan menghalalkan segala cara.

\section{Keberlangsungan}

Target yang telah dicapai dengan pertumbuhan setiap tahunnya harus dijaga keberlangsungannya agar perusahaan dapat dan tetap exis dalam kurun waktu yang lama.

\section{Keberkahan.}

Semua tujuan yang telah tercapai tidak akan berarti apa-apa jika tidak ada keberkahan di dalamnya. Maka bisnis Islam menempatkan berkah sebagai tujuan inti, karena ia merupakan bentuk dari diterimanya segala aktivitas manusia. Keberkahan ini menjadi bukti bahwa bisnis yang dilakukan oleh pengusaha muslim telah mendapat ridha dari Allah SWT dan bernilai ibadah.

\section{Riba Perspektif Etika Bisnis Islam}

Etika adalah cabang filsafat yang mempelajari baik buruknya perilaku manusia. Kerena itu etika dalam segi ini sering juga disebut "filsafat 
praktis"(Bartens, 2000: 35). Apabila ditambah dengan bisnis -etika bisnisberarti sebuah filsafat praktis yang membahas seputar bisnis.

Etika dalam ekonomi (bisnis) mengkaji tentang ekonomi atau bisnis yang memiliki etika sebagaimana wilayah-wilayah lain dari segi kehidupan manusia, seperti politik, budaya, sosial dan sebagainya. Artinya etika dalam hal ini belum merupakan suatu topik tersendiri. Ia masih sebagai cabang satu topik bernama ekonomi (bisnis). Kemudian pada tahun 1970-an etika ekonomi (bisnis) baru muncul sebagai satu topik tersendiri yang terlepas dari kerangka topik ekonomi (bisnis) (Bartens, 2000: 37).

Joan Robinson mensyaratkan tiga hal untuk suatu sistem ekonomi: memiliki suatu aturan, idiologi untuk membenarkan, dan suatu suara hati individu membuat ia bekerja keras kearah tujuan. Dimensi etis-lah yang sering dilupakan (Warde, 2001: 62).

Sistem etik ekonomi menekankan produk, kewajaran dan kejujuran di dalam perdagangan serta kompetisi yang adil (QS. 17: 35, 26: 181-183, 104: 2-4). Perihal pertimbangan yang etik untuk larangan riba, terdapat tiga hal, riba secara tidak wajar, eksploitasi dan tidak produktif. Bunga dalam pandangan tradisional mendasarkan hubungan antara pemberi pinjaman dan peminjam, dalam hal ini peminjam sendiri baik dia rugi ataupun mendapat manfaat ditanggung sendiri. Sebaliknya pemberi pinjaman mencari uang tanpa tegantung dengan hasil bisnis spekulasi tersebut. Islam menyukai resiko kerugian ditanggung bersama dengan kesepakatan oleh keduanya. Dalam hal ini Islam menolak gharar yang selalu spekulatif (Warde, 2001: 62).

Ketika Islam melarang riba dan gharar, itu disebabkan karena riba dan gharar merupakan suatu sikap yang menyalahi nilai-nilai yang telah ada dalam Islam itu sendiri, baik dari segi etika, moral dan akhlak. Secara umum nilai-nilai (etika) Islam dirangkum dalam empat prinsip pokok:

1. Tauhid. Prinsip ini mengantarkan manusia mengakui bahwa keesaan Allah mengandung konsekuensi keyakinan bahwa segala sesuatu bersumber serta kesudahannya berakhir kepada Allah. Prinsip ini menghasilkan "kesatuan- 
kesatuan" yang beredar dalam orbit tauhid. Kesatuan itu antara lain, kesatuan kemanusiaan, kesatuan alam raya, kesatuan dunia dan akherat.

2. Keseimbangan. Prinsip ini mengantarkan manusia Muslim meyakini bahwa segala sesuatu diciptakan Allah dalam keadaan seimbang dan serasi (QS. AlMulk [67]: 3). Prinsip ini menuntun prinsip-prinsip yang lainnya.

3. Kehendak bebas. Merupakan prinsip yang mengantarkan seorang Muslim meyakini bahwa Allah memiliki kebebasan mutlak, namun juga Allah memberikan kebebasan kepada manusia untuk memilih jalannya sendiri, baik itu yang baik ataupun yang buruk. Inilah kemudian, dasar lahirnya prinsip tanggung jawab.

4. Tanggung jawab. Manusia sebagai individu dan kolektivitas mempunyai kebebasan penuh untuk menentukan nasibnya sendiri, tapi harus sesuai dengan kaidah-kaidah Islam (Quraish, 1998: 409).

Dengan menjadikan wahyu sebagai pengetahuan tertinggi tentang kriteria yang baik dan yang buruk, maka ajaran Islam tentang etika dan moral bersifat mutlak, yang menganggap riba dan gharar merupakan suatu bentuk yang menyalahi kaedah moral dan etika Islam. Selain bersifat mutlak tersebut etika Islam juga sifatnya permanen, eternal dan universal. Ia tidak tunduk terhadap ruang dan waktu tapi mangatasi ruang dan waktu. Nilai-nilai moral dalam Islam berlaku untuk semua orang dan semua tempat tanpa memandang latar belakang etnis kesukuan, kebangsaan, dan keadaan sosio kultural serta lingkungan geografis mereka. Dalam Islam hanya terdapat kode moral untuk semua orang.

Nilai-nilai moral yang diajarkan oleh Islam mempunyai kesetabilan keserbatetapan dan ketegasan sebagaimana dinyatakan oleh Allah dalam struktur ajaran-ajaran-Nya yang berbentuk suruhan dan larangan. Apa yang disuruh oleh Allah adalah baik maka itu harus dikerjakan, sedang apa yang dilarang-Nya adalah buruk dan oleh kerena itu ia harus ditinggalkan. Sementara itu Islam juga menyediakan sanksi-sanksi untuk mempertahankan cita-cita etis ini.

Tepat sekali apa yang dikatakan oleh Mukti Ali, "agama memberi petunjuk bagaimana moral (etika, akhlak) itu dijalankan. Agamalah yang memberikan hukum-hukum moral dan karenanya agamalah yang memberikan 
sanksi yang terakhir dari semua tindakan-tindakan moral (Ismail, 2003: 258). Sementara itu pula, Islam mengajarkan seperangkat latihan-latihan peribadatan sholat misalnya - yang dimaksudkan untuk membina dan mengantarkan manusia ketingkat pencapaian kualitas moral yang luhur dan mulia. Seperti yang dititahkan oleh Allah, "dan kerjakanlah shalat, sebab sesungguhnya sholat itu mencegah dari perbuatan-perbuatan yang keji dan munkar" (al-Ankabut: 45).

Sejarah menunjukkan bahwa Agama Abraham dalam berbagai hal, melihat konsep ekonomi semuanya menekankan pada kedilan melalui gaji dan harga, mengkeritik spekulasi dan konsumsi pemboros, dan mendukung adanya etika dalam perdagangan.

Dalam pandangan kapitalis, memperkerjakan uang merupakan suatu hal yang sudah umum. Di Mesopotamia masa lampau, Hamurabi (1800 SM) memberikan batas maksimal tentang bunga dan mengutuk bunga majemuk. Aristotle juga menyajikan argumentasi yang paling berpengaruh tentang mandulnya uang, haruslah ditukarkan dengan tidak melipat gandakan. Orangorang Roma, juga mengizinkan bunga tetap tidak mengatur rata-rata bunga.

Agama Yahudi, Kristen, dan Islam mempertimbangkan bahwa pemberi pinjaman, menurut defenisi, menguasai suatu gudang modal yang melewati kebutuhannya, sedang peminjam kekurangan sumber daya untuk mencukupi kebutuhannya segera. Sangat tidak wajar jika seandainya kaum pakir miskin meminjam dan membayar kembali modal, hanya untuk meingkatkan pemberi pinjaman dengan pembayaran bunga, terutama ketika bunga juga berbunga.

Di Eropa pertengahan, kutukan pada riba telah berulang kali ditegaskan. Hanya di Gereja, di Lateran Dewan, menegesah bunga pada kredit terjamin. Walaupun masih mengambil waktu yang lama sebelum gagasan tersebut diterima penuh. Pendekatan terus meningkat dan sulit dipisahkan, hanya meminjamkan uang yang tengah berhasil dilakukan. Barangkali suatu hal yang berhasil adalah upaya dalam menggagas untuk menyetujui kredit komersil (Warde, 2001: 65).

Sedangkan di Amerika Serikat, di samping kekuasaan pasar bebas akan idiologi, ada suatu kecurigaan bagi pemberi modal dan bank. Ketika menyangkut kontroversi atas bank Amerika Serikat, Thomas Jeferson beragumentasi, bahwa 
spekulan, kreditur, dan orang-orang kaya pemegang saham bank mengambil untung dari utang negara dan dalam kemakmuran umum atau kesejahteraan publik, kecuali sepanjang mereka manghasilkan hasil pajak untuk membayar kekayaannya (Warde, 2001: 65).

Dari apa yang telah dipaparkan di atas mengenai riba, sedikit berbeda dengan apa yang ditulis dalam buku Islamic Business and Economic Ethics ini. Dimana riba tidak dapat dilepaskan dari teori batas (nazhariyyah al-hudud). Batas-batas itu antara lain batas bawah (al-hadd al-adna) dan batas atas (al-hadd al- 'ala). Batas bawah adalah minimum dari tuntutan hukum, dan batas atas adalah batas maksimum. Riba sendiri damasukkan dalam golongan batas atas yang positif (+), sedangkan batas bawah yang negatif (-) berupa zakat. Batas bawah bisa dilampaui, yakni dengan memberikan sedekah sunah, di samping membayar zakat di samping hukumnya wajib. Diantara kedua batas tersebut (positif dan negatif) terdapat keadaan bernilai nol, dengan wujud pemberian kredit tanpa bunga (qard al-hasan) (Rivai, 2012: 99).

Dari pandangan-pandangan yang ada tentang riba, penulis buku Islamic Business and Economic Ethics ini menjelaskan bahwa, bagi pengusaha yang notabene bukan penerima zakat (muzakki), kredit yang diberikan dapat dipungut bunganya dengan ketentuan yang tidak boleh melampaui batas yang telah ditentukan. Batas atasnya adalah jumlah beban bunga yang harus dibayar sama dengan jumlah hutang pokoknya (Rivai, 2012: 108). Lebih lanjut dijelaskan bahwa aturan riba dalam islam bersifat dinamis dan elastis, penerapannya dapat mempertimbangkan kondisi obyektif para pihak yang terlibat dalam perikatan bisnis (Rivai, 2012: 100).

\section{Penutup}

Buku ini ditulis untuk menjawab tantangan dan kondisi bisnis saat ini yang semakin jauh dari etika bisnis yang baik dan dapat diterima oleh semua kalangan, baik itu stakeholder maupun masyarakat. Banyak perusahaan-perusahaan melakukan kompetisi dengan tidak sehat yang telah jauh dari nilai-nilai agama dan norma. 
Buku ini disajikan dengan pendekatan praktik Rasulullah saw. dalam berbisnis sebagaimana tertera dalam al-Qur'an dan Hadis, sehingga semua pihak merasa dipuaskan dalam konteks berbisnis yang berakhlaqul karimah, baik dari sisi pengusaha maupun dari sisi konsumen. Berbisnis secara islami dapat memberikan kepuasan dan keikhlasan tersendiri, kerena tidak ada yang merasa dirugikan sebab semua kegiatan dilakukan dalam konteks ibadah.

\section{DAFTAR PUSTAKA}

Abdullah, Yatim, Pengantar Studi Etika, Jakarta: Raja Grafindo Persada, 2006.

Abidin Ahmad, Zainal, Dasar-Dasar Ekonomi Islam, Jakarta: Bulan Bintang, 1979.

Adiwarman, Karim, Bank Islam: Analisis Fiqh dan Keungan, Jakarta: Raja Grafindo Persada, 2004.

Agoes, Sukrisno dan I Cenik Ardana, Etika Bisnis Dan Profesi; Tantangan Membangun Manusia Seutuhnya, Jakarta: Selemba Empat, 2009.

Amin, Ahmad, Etika, Jakarta: Bulan Bintang, 1995.

Baqi, Fu'ad Abdul, Mu'jam al-Mufahrasy, Kairo: Darul Fikr, 1981.

Muhamad, Sistem dan Prosedur Oprasional Bank Syari'ah, Yogyakarta: UUI Press, 2000.

Muhamad dan Alimin, Etika dan Perlindungan Konsumen dalam Ekonomi Islam, Yogyakarta: BPFE, 2004

Munawir, al-, Wirson Kamus al-Munawwir, Yogyakarta: Pustaka Progresif, 1984.

Mustofa, A, Akhlak Tasawuf, Bandung : Pustaka Setia, 1997.

Nasir, Salihun A, Tinjauan Akhlak, Surabaya: al-Ikhlas, 1991.

Qardhawi, Al-, Yusuf Halal dan Haram Dalam Islam, terj. Muammal Hamidy Surabaya: Bina Ilmu, 1993.

Rahman, Afzalur, Doktrin Ekonomi Islam, Jakarta: 1997.

Rivai,Veithzal, Amiur Nuruddin, dan Faisar Ananda Arfa, Islamic Business and Economic Ethics: Mengacu pada al-Qur'an dan Mengikuti Jejak Rasulullah SAW dalam Bisnis, Keuangan, dan Ekonomi, Bumi Aksara, 2012.

Said, H. Muh, Etika Masyarakat Indonesia, Jakarta: Pradya Paramita, 1980.

Shihab, Quraish, Wawasan Al-Qur'an, Jakarta: Mizan, 2004. 
Sidiktono, dkk, ed. Ainur Rahim Faqih dan Amir Muallim, Ibadah dan Akhlak Dalam Islam, cet. ke-1, Yogyakarta : UII Press, 1998.

Titus, Harol H. dkk, Persoalan-Persoalan Filsafat, terj. H. M. Rasjidi, Jakarta: Bulan Bintang, 1984.

Yusanto, Muhammad Ismail dan Muhammad Karebet Widjajakusuma, Menggagas Bisnis Islami, Jakarta: Gema Insani Press, 2002. 